\title{
Coryneform Bacteria Producing Methane Thiol
}

\author{
By M. ELISABETH SHARPE, B. A. LAW AND B. A. PHILLIPS \\ National Institute for Research in Dairying, Shinfield, Reading RG2 9AT, Berkshire
}

(Received 8 December 1975)

INTRODUCTION

Recent work on Cheddar cheese flavour has implicated methane thiol $\left(\mathrm{CH}_{3} \mathrm{SH}\right)$ as an important constituent of Cheddar aroma (Manning \& Robinson, 1973; Manning, 1974). To determine whether this compound might be a metabolite of the bacterial flora of the cheese, isolates from milk and Cheddar cheese were examined for their ability to produce methane thiol. Among such isolates were a number of methane thiol-producing coryneform bacteria. Although methane thiol-producing bacteria have been described previously (Kadota \& Ishida, 1972), we are not aware of any reports that coryneform bacteria have this ability. Accordingly these organisms are described in this paper.

\section{METHODS}

Isolates. Strains were isolated from raw milk and from homogenates of cheese curd and Cheddar cheese by enrichment using a mineral mix [containing $(\%): \mathrm{K}_{2} \mathrm{HPO}_{4}, 0 \cdot 2 ; \mathrm{KH}_{2} \mathrm{PO}_{4}$, $0 . \mathrm{I} ; \mathrm{CaCl}_{2} .2 \mathrm{H}_{2} \mathrm{O}, 0 . \mathrm{I} ; \mathrm{MgCl}_{2} .6 \mathrm{H}_{2} \mathrm{O}, 0.0 \mathrm{I} ; \mathrm{FeCl}_{2} .6 \mathrm{H}_{2} \mathrm{O}$, 0.00I ] plus $0.5 \%$ DL-methionine, or by direct plating on milk agar (skim-milk, $30 \%$; agar, $2 \%$ ). All isolates were tested for the production of methane thiol from L-methionine (see below). Positive strains were examined microscopically, and representative cornyeform bacteria were tested physiologically, and examined for the presence or absence of meso or LL-diaminopimelic (DAP) acids and of arabinose in the cell wall.

Laboratory strains. Reference strains of Arthrobacter tumescens NCIB8914, Brevibacterium linens $\mathrm{NCIB} 8546$ and non-pigmented grey-white strains of coryneform bacteria, previously isolated from Limburger and Meshanger cheese by Mulder et al. (1966) and further described by Crombach (1972, 1974), were included for comparison in many tests.

General culture of strains. Oxoid Nutrient Broth (NB) or Nutrient Agar (NA) were used. Cultures were incubated at $30{ }^{\circ} \mathrm{C}$ unless otherwise stated.

\section{Tests for physiological characteristics}

Catalase was detected after 2 days incubation in NB, using the method of Harrigan \& McCance (I966).

Optimum growth temperatures were determined by measuring extinctions at $580 \mathrm{~nm}$ after growth in NB for 4 days at 22, 30,37, and $40{ }^{\circ} \mathrm{C}$ (Lumetron Colorimeter model $40 \mathrm{I}$, Photovolt Corp., New York, U.S.A.).

Heat resistance: cultures $(0.1 \mathrm{ml})$ were inoculated into $\mathrm{NB}$, heated to $60 \pm 0.1{ }^{\circ} \mathrm{C}$ for $30 \mathrm{~min}$, and then plated on NA.

Morphological changes were observed on the EYGA medium described by Cure \& Keddie (1972).

Aerobic growth: tested according to the method of Hugh \& Leifson (I953). 
Anaerobic growth: boiled yeast-glucose broth (YGB) (Naylor \& Sharpe, 1958) was inoculated and incubated for 3 days in an anaerobic jar under $90 \%$ hydrogen plus $10 \%$ carbon dioxide.

Oxidase was detected by the method of Kovacs (1956).

Pigmentation: (i) pigment formation on milk agar was observed; (ii) organisms grown in NA were tested for the presence of a carotenoid-like pigment (Jones, Watkins \& Erickson, 1973).

Proteolysis was tested using milk agar (clearing zones) and gelatin (liquefaction) as substrates.

Salt tolerance was tested using Owens \& Keddie's (1969) Mineral Base E (prepared as described by Cure \& Keddie, 1972), supplemented with $0.2 \%$ (w/v) yeast extract, $0.1 \%$ $(\mathrm{w} / \mathrm{v})$ glucose and $5,6,10,12$ or $15 \%(\mathrm{w} / \mathrm{v}) \mathrm{NaCl}$.

Carbohydrate utilization: growth in Owens \& Keddie's (1969) Mineral Base E, supplemented with $0.02 \%(\mathrm{w} / \mathrm{v})$ yeast extract and either $0.5 \%(\mathrm{w} / \mathrm{v})$ glucose, lactose, sucrose, glycerol or inulin, or $0.2 \%(\mathrm{w} / \mathrm{v})$ citrate, lactate or acetate, was measured as $E_{580}$.

Nutritional requirements. Owens \& Keddie's (1969) Mineral Base E - N (which does not contain an ammonium salt) was supplemented with each of the following $(\%, w / v)$ : $\left(\mathrm{NH}_{4}\right)_{2} \mathrm{SO}_{4}, 0.0 \mathrm{I} ;\left(\mathrm{NH}_{4}\right)_{2} \mathrm{SO}_{4}$, 0.01, plus yeast extract, 0.2 ; methionine, 0.I; $\left(\mathrm{NH}_{4}\right)_{2} \mathrm{SO}_{4}$, $0.0 \mathrm{I}$, plus glucose, $0 . \mathrm{I}$. Three serial transfers were made in each medium and the presence or absence or growth was observed visually.

Acid end-products from glucose were determined after strains had been growing in YGB for 3 days, by the method of Latham \& Legakis (1976) using gas chromatography (GC).

Production of methane thiol from L-methionine. Strains grown on NA were suspended (to give an $E_{580}$ of 10 ) in $0.05 \mathrm{M}$-Tris- $\mathrm{HCl}$ buffer, $\mathrm{pH} 8.0$, with L-methionine $(66 \mathrm{mM})$ and incubated at $30^{\circ} \mathrm{C}$ for 2 to $6 \mathrm{~h}$ in a Conway diffusion unit, using the method of Ruiz-Herrera \& Starkey (1969). Methane thiol was trapped in $5 \%(\mathrm{w} / \mathrm{v})$ mercuric acetate in $10 \%(\mathrm{v} / \mathrm{v})$ acetic acid and estimated colorimetrically (Sainsbury \& Maw, I967). To confirm that methane thiol was being produced during incubation, portions of the mercuric acetate were acidified with $2 \mathrm{M}-\mathrm{HCl}$ to release the thiol from the mercaptide, and the head space $(5 \mathrm{ml})$ was analysed by GC (Manning, 1974) with authentic methane thiol as a reference.

\section{Cell-wall analysis}

Diamino acids. Organisms were grown on NA for $48 \mathrm{~h}$ and walls were prepared from whole cells by the rapid method of Schleifer \& Kandler (1972). The sample was hydrolysed with $6 \mathrm{M}-\mathrm{HCl}$ at $100^{\circ} \mathrm{C}$ for $6 \mathrm{~h}$ and examined for diamino acids, using the paper chromatographic method of Rhuland et al. (1955).

Carbohydrates. Using the method of I. J. Bousfield (personal communication), organisms were grown on NA for $48 \mathrm{~h}$ and walls prepared by digestion of washed whole cells with $5 \% \mathrm{KOH}$ for $5 \mathrm{~min}$ at $120^{\circ} \mathrm{C}$. The residual washed walls were hydrolysed with $2 \mathrm{M}-\mathrm{HCl}$ at $100{ }^{\circ} \mathrm{C}$ for $3 \mathrm{~h}$ and carbohydrates detected by thin-layer chromatography, as described by Lechevalier (1968). Corynebacteria with known wall compositions were included as controls.

\section{RESULTS AND DISCUSSION}

Isolates. Four strains producing methane thiol from L-methionine and isolated on different occasions from raw milk (strain R6, NCDO205I), cheese curd (C4, NCDO2050) and Cheddar cheese (CMDI, NCDO2048 and CMD3, NCDO2049) were examined. All were Grampositive, club-shaped rather irregular rods, catalase positive, oxidase negative, non-motile, 
non-sporing and grew well aerobically, but not at all anaerobically. The seven reference strains had these same characteristics.

Morphology. After 2 days, the club-shaped rods had become coccoid in all four strains.

Growth requirements. Only strains CMDI and CMD3 were tested. They would not grow in the presence of added ammonium salt or L-methionine but grew after three transfers in the presence of ammonium salt plus yeast extract or ammonium salt plus glucose, indicating that exogenous organic growth factors were not required, and that they were nutritionally non-exacting.

Acid end-products from glucose. The only volatile acid produced was acetate. The absence of propionate, profuse aerobic growth and absence of anaerobic growth excluded relationships with propionibacteria.

Table i summarizes the characteristics of the isolates and of the reference strains. None of the reference strains produced methane thiol from L-methionine.

\section{Possible classification of isolates}

In the coryneform bacteria, the diamino acid present in the wall (meso-DAP, LL-DAP, ornithine, diaminobutyric acid or lysine), and the presence or absence of arabinose in walls containing meso-DAP, are characteristic for certain species or groups (Schleifer \& Kandler, 1972). R. M. Keddie (personal communication) has devised a tentative scheme for the recognition of some taxa within the coryneform bacteria, based on these characteristics and other criteria. Our strains contained meso-DAP, but not arabinose in the cell wall (Table 1). Coryneform bacteria known to contain meso-DAP in their walls include Corynebacterium sensu stricto, the 'rhodochrous' complex (Goodfellow, Fleming \& Sackin, 1972) and B. linens. The absence of arabinose in our strains excluded a relationship with the genus Corynebacterium or the 'rhodochrous' complex and suggested that they be compared with $B$. linens. The lack of relationship with Corynebacterium was confirmed by the presence of a growth cycle (rods $\rightarrow$ cocci) and the obligate aerobic nature of the growth in our isolates. In addition, M. Goodfellow (personal communication) has shown that our strains, like B. linens, but unlike Corynebacterium and the 'rhodochrous' complex, do not contain mycolic acids. Jones (1975) has grouped coryneform and related bacteria into a number of clusters by computer analysis, and there was a general but inconclusive trend for our isolates to show similarities to her clusters $\mathrm{F}_{4}$ and $\mathrm{F}_{5}$ which include strains of $B$. linens. Like $B$. linens, our strains also have a high degree of salt tolerance.

However our methane thiol-producing isolates differ from $B$. linens in that they do not produce the carotenoid-like orange pigment (Jones et al., 1973) found in the latter. They differ from $B$. linens $\mathrm{NCIB} 8546$ in being proteolytic, utilizing lactate and sucrose, giving an acid and not an alkaline reaction in Hugh \& Leifson medium, in having an optimum growth temperature between $30^{\circ}$ and $37^{\circ} \mathrm{C}$ and in being able to grow at $40^{\circ} \mathrm{C}$. The grey-white cheese strains of Mulder et al. (1966) also differ from ours in cell-wall composition, optimum growth temperature, pigmentation and stimulatory effect of salt. Among these cheese strains, Crombach (1972, 1974) has distinguished two different groups by DNA homology and by physiological characteristics (strains AC253 and EC20 falling into one group, and $\mathrm{AC} 256, \mathrm{AC} 263$ and $\mathrm{ECI} 6$ into the other) and these groups are confirmed here by their different cell-wall compositions, as Keddie has also noted (personal communication). Our strains also appear to be different from the four groups of coryneform bacteria isolated from milk and cheese by Jayne-Williams \& Skerman (I966).

Although the methane thiol-producing strains are similar to $B$. linens in cell-wall composition, they differ in other respects. Bousfield (1972) points out that the taxonomy of the 
Table I. Physiological characteristics and some wall constituents of methane thiol-producing coryneform bacteria and of reference strains

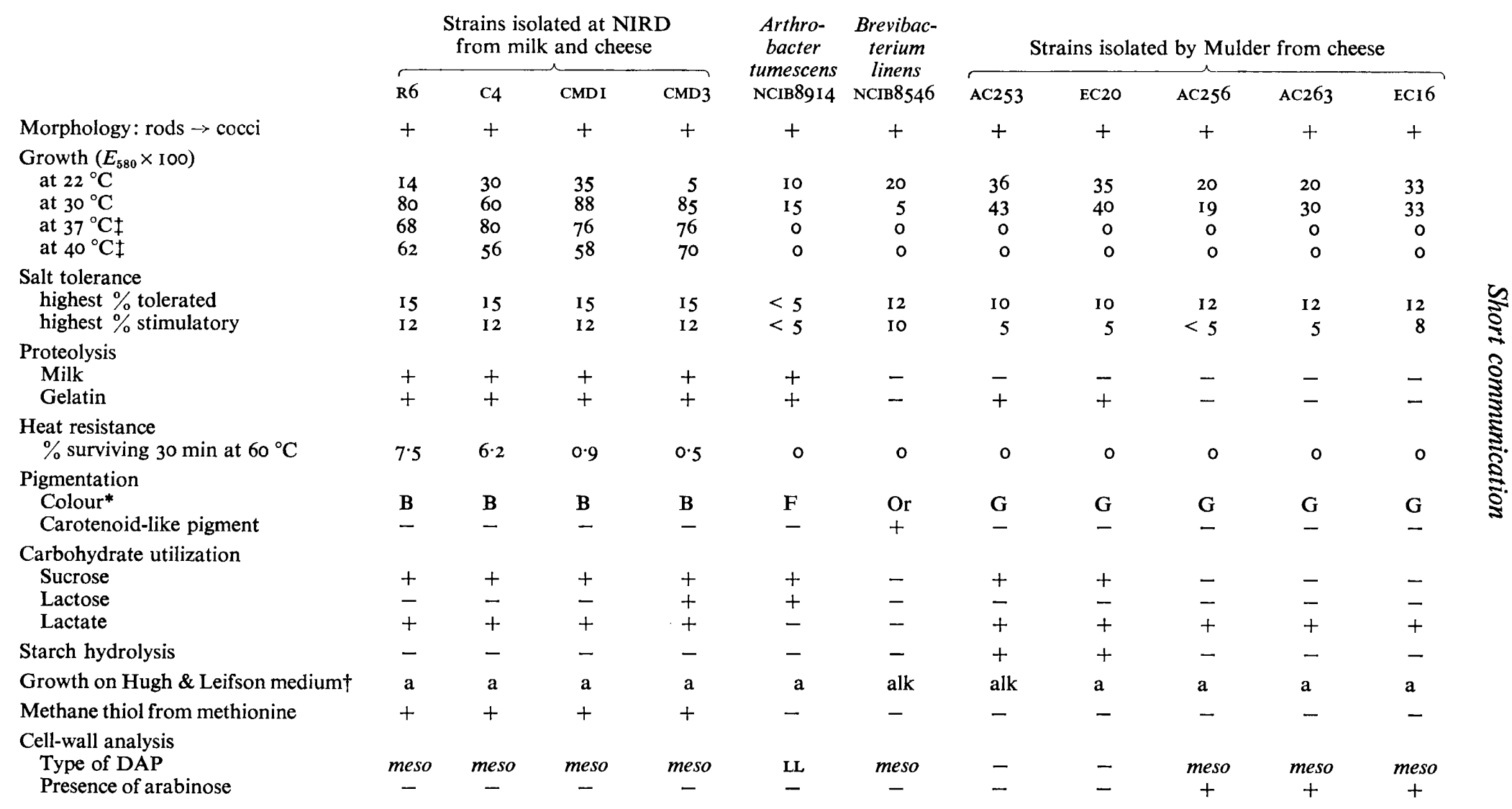

All strains utilized glucose and acetate. None utilized inulin or citrate.

* B, pale brown, water soluble; F, fawn; Or, orange; G, grey.

$\dagger$ a, aerobic growth acid; alk, aerobic growth alkaline. 
genus Brevibacterium is unsatisfactory, and both he and Bergey's Manual of Determinative Bacteriology (I974) consider the genus to be a mere repository for a variety of Gram-positive organisms. In Bergey's Manual of Determinative Bacteriology (1974), the genus is regarded as a genus incertae sedis. Our strains must therefore remain as anclassified member of the 'Coryneform Group of Bacteria' (Bergey's Manual of Determinative Bacteriology, 1974).

The production of methane thiol by these coryneform bacteria makes them of interest in flavour studies, although their natural habitat is unlikely to be milk. Their high growth temperatures suggest a human or animal origin, and, because of their halophilic nature, possibly skin.

\section{Characteristics of methane thiol-producing coryneform bacteria}

They possess a growth cycle (rods $\rightarrow$ cocci); achieve optimum growth between 30 and $37^{\circ} \mathrm{C}$; are strict aerobes; are stimulated by as much as $\mathrm{I} 2 \% \mathrm{NaCl}$; are proteolytic; slowly produce a pale brown water soluble pigment; utilize acetate and lactate; produce some acetic acid from glucose; and their cell walls contain meso-DAP but no arabinose.

The four strains described here are deposited with the National Collection of Dairy Organisms.

The authors are greatly indebted to Dr R. M. Keddie for much helpful advice and discussion and for reference strains. They also wish to thank Dr M. Goodfellow for examining strains for mycolic acids, Dr M. J. Latham for performing gas chromatography, Dr I. J. Bousfield for methods of cell-wall analysis, Dr W. H. J. Crombach for reference strains, and Mrs W. E. G. Krzanowski for technical assistance.

\section{REFERENCES}

Bergey's Manual of Determinative Bacteriology, 8th edn (1974). Edited by R. E. Buchanan and N. E. Gibbons. Baltimore: Williams and Wilkins.

BousfieLd, I. J. (1972). A taxonomic study of some coryneform bacteria. Journal of General Microbiology 7I, $44 \mathrm{I}-455$.

CROMBACH, W. H. J (1972). DNA base composition of soil arthrobacters and other coryneforms from cheese and sea fish. Antonie ran Leeuwenhoek 38, I05-I 20.

Сromвach, W. H. J. (1974). Relationships among coryneform bacteria from soil, cheese and sea fish. Antonie van Leewwenhoek 40,347-359.

CURE, G. L. \& KedDIE, R. M. (1972). Methods for the morphological examination of aerobic corynebacteria. In Sampling - Microbiological Monitoring of Environments, Society for Applied Bacteriology Technical series 7, pp. I23-135. Edited by R. G. Board and D. W. Lovelock. New York and London: Academic.

Goodfellow, M., Fleming, A., \& SACKIN, M. J. (1972). Numerical classification of 'Mycobacterium rhodochrous' and Runyon's group IV Mycobacteria. International Journal of Systematic Bacteriology 22, $8 \mathrm{I}-98$.

HaRrigan, W. F., \& MCCANCE, M. E. (1966). Laboratory Methods in Microbiology, p. I66. London and New York: Academic.

Hugh, R. \& Leifson, E. (I 953). The taxonomic significance of fermentative versus oxidative metabolism of carbohydrates by various gram-negative bacteria. Journal of Bacteriology 66, 24-26.

Jayne-Williams, D. J., \& Skerman, T. M. (1966). Comparative studies on coryneform bacteria from milk and dairy sources. Journal of Applied Bacteriology 29, 72-92.

JONES, D. (1975). A numerical taxonomic study of coryneform and related bacteria. Journal of General Microbiology 87, 52-96.

Jones, D., WAtKINS, J. \& ERICKson, S. K. (1973). Taxonomically significant colour changes in Brevibacterium linens probably associated with a carotenoid-like pigment. Journal of General Microbiology 77, $145-150$.

KADOTA, H. \& IsHidA, Y. (1972). Production of volatile sulphur compounds by micro-organisms. Annual Review of Microbiology 26, 127-138.

Kovacs, N. (1956). Identification of Pseudomonas pyocyanea by the oxidase reaction. Nature, London $\mathbf{1 7 8}$, 703 . 
LATHAM, M. J. \& Legakis, N. J. (1976). Cultural factors influencing the utilization or production of acetate by Butyrivibrio fibrisolvens. Journal of General Microbiology 94. 380-388.

LeChevalier, M. P. (1968). Identification of aerobic actinomycetes of clinical importance. Journal of Laboratory and Clinical Medicine 7x, 934-944.

MANNING, D. J. (1974). Sulphur compounds in relation to Cheddar cheese flavour. Journal of Dairy Research 4I, 8I-87.

Manning, D. J. \& Robinson, H. M. (1973). The analysis of volatile substances associated with Cheddar cheese aroma. Journal of Dairy Research 40, 63-73.

Mulder, E. G., Adamse, A. D., Antheunisse, J., Deinema, M. H., Woldendorp, J. W. \& Zevenhuizen, L. P. T. M. (1966). The relationhip between Brevibacterium linens and bacteria of the genus Arthrobacter. Journal of Applied Bacteriology, 29, 44-7I.

NAYLOR, J. \& ShARPE, M. E. (1958). Lactobacilli in Cheddar cheese. r. The use of selective media for isolation and serological typing for identification. Journal of Dairy Research 25, 92-103.

Owens, J. D. \& KeDDIE, R. M. (1969). The nitrogen nutrition of soil and herbage coryneform bacteria. Journal of Applied Bacteriology 32, 338-347.

Rhuland, L. E., Work, E., Denman, R. F. \& Hoare, D. S. (I955). The behaviour of isomers of $\alpha, \epsilon$-diaminopimelic acid on paper chromatograms. Journal of the American Chemical Society 77, 4844-4846.

Ruiz-Herrera, J. \& Starkey, R. L. (1969). Dissimilation of methionine by a demethiolase of Aspergillus species. Journal of Bacteriology, 99, 764-770.

Sainsbury, D. M. \& MAW, G. A. (1967). On the determination of volatile thiols in beer. Journal of the Institute of Brewing 73, 293-297.

SCHLEIfER, K. H. \& KandleR, O. (1972). Peptidoglycan types of bacterial cell walls and their taxonomic implications. Bacteriological Reviews 36, 407-477. 